\title{
Valuation of Economic Utilization of Fish Processing Waste Patin (Pangasius Hypopthalmus) as an Added Value for Fish Processing Industry Players in the District Kampar, Riau
}

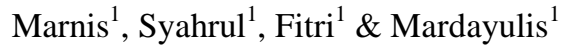 \\ ${ }^{1}$ State University Riau, Indonesia \\ Correspondence: Priyono, Post Graduate Management Program, University Bina Darma Palembang, Indonesia. \\ E-mail: priyono.unu_sidoarjo@yahoo.com
}

Received: July 4, 2016

doi:10.5539/ijef.v8n9p104
Accepted: July 26, 2016

Online Published: August 25, 2016

\begin{abstract}
At this time there is no productive enterprise specializing in the utilization of solid waste from the processing of catfish into industrial raw materials of food and fish feed. Chances are this is due to the unavailability of data and information adequate technical and economical. In order to meet the needs that the research was conducted. This study aimed to analyze the economic valuation of the utilization of industrial solid waste processing of catfish, the raw material of functional food and feed that meet the quality standards in accordance with the National Standards Indonnesia (SNI) as well as to determine on whether viable or not the establishment of the business of processing food and feed of waste solid results catfish processing household or industrial scale. This research was a laboratory scale experiments using technology that has undergone several modifications. The results showed that the technology is able to produce industrial raw materials in the form of Fish Protein Concentrate (KPI), fish oil, bone powder and pyloric caeca crude enzyme in accordance with the Indonesian National Standard. Judging from the environmental impact assessment and business analysis (Gross Benefit Cost Ratio = $1.15>1$ ), amounting to 2,607 Profitabilty Ratio> 1 , and an IRR of $65.91>18 \%$, then the utilization of solid waste business establishment catfish processing household scale feasible.
\end{abstract}

Keywords: economic valuation, solid waste catfish and industrial raw materials

\section{Introduction}

Kampar Regency is one of the areas of cluster development of aquaculture catfish (Pangasius hypopthalmus) nationally by the Ministry of Marine Affairs and Fisheries. This is because the production of catfish Riau in 2012 amounted to 60 thousand tons and an increase every year. Upstream of success must be accompanied also by downstream, so that price stability can be maintained especially when production is abundant. Thus diversifying the processing of catfish into the solution, either traditional or processed fish preparations modern. Dewita research results and Syahrul (2012) states that diversification catfish processing in the form of fish protein concentrate (KPI) and applied to a wide range of processed products based KPI catfish can boost the nutritional value of the product; even improve the nutritional status of children under five malnutrition becomes normal again after the intervention of street food such as instant porridge, cookies and snacks. In the district of Kampar there Patin Fish Processing Centers are producing fish fillets, smoked fish, salted fish, shredded fish, nuggets, burgers and more based catfish.

Catfish processing industry activities will lead to a positive impact and the negative impact for both industry players as well as the surrounding community. The growing catfish processing industry will also be able to produce waste that much anyway, causing problems for the surrounding environment. Currently the problem of pollution increasingly attracted the attention of the community, especially within the last few years. Industry develops so rapidly, including catfish processing industry is one of the causes disturbance to the environment. Thus the handling of the problem of environmental pollution proper and efficient very helpful program sustainable development.

Production activities at the Center Catfish Processing Kampar, of course, produce waste in the form of liquid and solid wastes. Liquid waste from water washing when handling fish prior to processing; while the solid waste in the form of the head, fins, tail, bones, entrails (intestines), and abdominal fat. Generally, the amount of solid 
waste generated approximately $40-60 \%$. If the solid waste is not there handling, certainly can interfere with the environment, good for water, air, soil, and the surrounding population.

Based on the above problems, it can be concluded that the catfish processing industry is still cause environmental problems that must be addressed. this circumstances has motivated the author to conduct further research in order to solid waste generated by the processing industry catfish big enough that can be harnessed into economically valuable products, thus increasing revenue industrialists and surrounding communities and do not disturb the environment.

\section{Literature Review}

\subsection{Characteristics Catfish}

Iridescent shark (Pangasius hypophthalmus) is a type of catfish that is widely cultivated in Indonesia, because the catfish Siamese have rapid growth and high fecundity eggs. In English catfish is popular as an other name catfish cat fish because of having "whiskers". Patin conjoined with the Latin name hypopthalmus Pangasius catfish is a catfish bangkok's or because it came from Bangkok (Thailand).

Siamese catfish is a fish consumption, long-bodied white silver with a bluish backs. Saanin (1986), classifies Catfish following classes: Pisces, sub-classes: Teleostei, order: Ostariophysi, suborder: Siluroidea, family: Pangasidae, genus: Pangasius. Catfish has a large body size, can weigh $20 \mathrm{~kg} / \mathrm{head}$, or even more. Shaped flat body and height, and length, ie the length can reach $120 \mathrm{~cm}$ or even more (Cahyono, 2010).

Siamese catfish meat as very thick and there is no thorn in the flesh. The meat is white and soft texture, has a very tasty and delicious taste. The percentage of beef (fillet) approximately $61.7 \%$ of the weight of fish (Khairuman \& Dodi Sudenda, 2009). The chemical composition Patin in 100 grams of fish meat can be seen in Table 1 below.

Table 1. Chemical composition Patin in 100 grams of fish meat

\begin{tabular}{lc}
\hline chemical composition & \% wet weight \\
\hline The protein content & 14,53 \\
Fat level & 1,02 \\
carbohydrate & 1,49 \\
ash content & 0,74 \\
Water content & 82,22 \\
\hline
\end{tabular}

Source: Maghfiroh (2000).

\subsection{Theory of Economic Value}

The economic value (economic values) in the neoclassical paradigm can be seen in terms of consumer satisfaction (preferences of consumers) and corporate profits (profit of firms). In this case the basic concept used is the economic surplus (economic surplus) obtained from the sum of surplus by consumers (consumers surplus; CS) and surplus by producers (producers surplus; PS), (Luky et al., 2007).

$\mathrm{He}$ also explained that the consumer surplus occurs when the maximum number of consumers who are able to pay more than that actually paid to acquire goods or services. The difference in the number of so-called consumers surplus (CS) and is not paid within the context of obtaining the desired item. Meanwhile, producer surplus (PS) occurs when the amount received by producers is greater than the amount that must be spent to produce a good or service. In principle the valuation refers to the contribution of commodities to achieve a particular purpose or value of a commodity depends on the specific objectives of the value it self.

\subsection{Economic Valuation Theory}

Economic valuation is the summation of individual preferences in a desire to pay (willingness to pay) to consume a good environment. Thus the economic valuation is a tool to measure the community's desire for a good environment against a bad neighborhood.

What is valued in an environment composed of two different categories, namely:

1. The value of people's preference to changes in the environment, so that people have a preference in the level of risk faced in his life, thus giving rise to the desire to pay willingnes to pay (WTP) so that the environment does not continue to deteriorate. It is included in the category of economic valuation (economic valuation), which is often expressed in the demand curve (demand curve) on the environment. 
2. Natural resources and the environment as the asset's life has intrinsic value. This is a form of intrinsic economic value (intrinsic values) of the existence of natural resources and the environment (Fahrudin, 2009).

As described previously, the economic value of a commodity (good) or services is defined as "how to pay" rather than "how much it costs to be incurred to provide goods / services". Thus, when the environment and its resources exist and provide goods and services for humans, the "ability to pay" (willingness to pay) is a proxy for the value of these resources, without questioning whether significant human performs payment processing (payment) or not.

The consumer surplus is the difference between the amount paid by the buyer for the product and willingness to pay. Consumer surplus arises because consumers received more than paid and the bonus is rooted in the law of diminishing marginal utility. Because the emergence of consumer surplus because consumers pay for each unit based on the value of the last unit. The consumer surplus reflects the benefits because they could buy all the units of goods at a low price rate

The same (Barton, 1994). Furthermore, it is stated that the market is functioning well, the market price reflects the marginal value, such as the last unit traded products reflect the value of the unit traded products. Thus in a simple consumer surplus can be measured as an area located between the demand curve and the price line.

The purpose of the study is to determine the valuation of Total Economic Value (TEV) use of natural resources and the environment. Where the value of TEV, is the sum of Value use, a value obtained from the use of direct or related to natural resources and the environment being studied or researched. This value consists of the value associated with commercial activities, subsistence, leisure and other activities linked to the natural resources that can be studied. While Use Indirect Value (In Direct Use Value), relating to the protection or support of economic activity and property supplied by a natural resource and Value Option (Option Use Value) value use of natural resources and the environment in the future. To Value To Indirect (In Direct Use Value) are values that no direct link with the possible use of natural resources and the environment, usually in the form of Existence Value and Bequest Value which is a total of the Value Existence (Existence Value) value is given (as solely) due to the existence of natural resources and the environment, plus the value of Inheritance (Bequest value) value is given to children and grand children to be inherited a natural resources and the environment (Spurgeon, JPG 1992).

To express how the continuation of natural resources and the environment is calculated, known as 2 (two) concept. First, the concept of sustainability and the strong, weak concept of sustainability. Dixon, J. A. and M. M. Hufschmidt. (1991) states that if the resource capital (capital) can be divided into natural resources and environmental capital (KN, natural capital), physical capital (KP, physical capital), capital and human resources (KH, human capital). Then the concept of sustainability Weak assume that all types (KN, natural capital), can be replaced with other types of capital (KP or KH).

\subsection{Definition Industry}

Industry is an attempt to produce the finished goods to raw materials or raw materials through the production process of cultivating in large quantities, so as to obtain the lowest possible price, but with the highest quality. In general definitions of industrial assortment sense but basically no different from one another, while the definition according to the company that runs Sukirno economic activities belonging to the secondary sector. The activities include textile factories, assembly plants and cigarette manufacturing plant. Some understanding of the industry in general can be concluded that the industry is a collection of several companies that produce certain goods and occupy a certain area with a production output of goods or services (Fahrudin \& Achmad, 2009).

\subsection{Definition of Waste}

Based on Government Regulation No. 18/1999 85/1999 Jo.PP, waste is defined as waste or effluent from a business and or human activity. Waste is an unused waste material negative impact on the community if not properly managed. Industrial wastewater or household (domestic) if not managed properly will have a negative impact on health.

Prevention and mitigation of the impact of wastewater on health can be done by identifying the type of waste, knowing the impact on health, and the processing method. At this time, the industry is growing rapidly. It can lead to environmental degradation. The environmental degradation caused by uncontrolled waste disposal and greenhouse gas emissions from industrial activities. Waste from industrial activities can be either liquid waste, gas, and solid.

Based on the type of compound that is produced, the waste can be divided into organic and non-organic waste. Organic waste has a different definition of that use can be adapted to the purpose classification. Based on the understanding chemically organic waste is any waste containing the elements carbon $(\mathrm{C})$, to include waste from 
living things (eg, animal and human feces, food waste, and the remains of dead plants). However, it is technically most people define organic waste as a waste that only comes from living things (natural) and the perishable nature. That is, organic materials decompose naturally but difficult / biodegradable, such as paper and synthetic organic materials (artificial) is also difficult to decompose / biodegrade, such as plastics and rubber, are not included in organic waste but classified inorganic waste. This applies especially when people separate solid waste (garbage) in landfills for waste processing purposes.

Organic waste derived from living things easily decomposed because in living things are the elements carbon (C) in the form of sugars (carbohydrates) which is relatively simple chemical chain so that it can be used as a source of nutrients for microorganisms, such as bacteria and function. The result of organic waste decomposition by microorganisms mostly in the form of methane $(\mathrm{CH} 4)$, which also can cause environmental problems

\subsection{Waste Management}

Food industrial waste (liquid, solid and gas) is needed to improve the achievement of the objectives of waste management (regulatory compliance), as well as to improve the efficiency of resource usage. In general, waste management is a series of activities that include the reduction, collection, deviations, transportation, utilization (reuse, recycling), processing (treatment), and / or landfilling (disposal).

The generation of waste from the food industry, well-waste liquid, solid or gas, can not be avoided entirely. After efforts minimization through process modification or utilization (with a net production), the next step should be done is a processing / handling these wastes to avoid environmental contamination. The main criterion waste management in general is the fulfillment of applicable standards with minimum cost. Cleaner Production focuses on the prevention of the formation of waste.

Where waste is one indicator of inefficiency, because it was such prevention efforts should be made to start from scratch (Waste avoidance), a reduction in the formation of waste (waste reduction) and utilization of waste formed through recycling (recycle). The success of these efforts will result in savings (savings) is remarkable for a significant reduction in production costs so this approach becomes a source of income (revenue generator).

CP (Cleaner Production) is a strategy to avoid the onset of industrial pollution through reduced waste generation (waste generation) at every stage of the production process to minimize or eliminate waste before any kind of potential contamination formed. Terms such as prevention Pollution (Pollution Prevention), reduction at source (Source Reduction), and Minimization of Waste are often included with the term CP (Cleaner Production) (Traffic Agency, 2010). Option of management in handling the waste that can be implemented in the food industry include:

\section{Prevention of the formation of waste that are abundant with practicing more efficient process technology}

2. Implementation of the recycling process of waste generated or use waste

as other industrial raw materials, and 3. The improvement of waste generated through waste treatment processes are systematically (Winiati P. Rahayu, 2008). Waste must be processed so as not to pollute the environment and endanger health. Waste should be managed to reduce pollution. Waste management can be done using machines to reduce harmful levels before discharge. For solid waste such as the processing of fish, processed using the incinerator.

\subsection{Clean Production}

Net production is its environmental management strategies that lead to prevention and integrated to be applied to the entire production cycle (UNIDO, 2002). Further stated that the net production goal is to increase productivity by providing a better level of efficiency in the use of raw materials, energy and water, encourage better environmental performance, through reduced waste generation sources and emissions and reduce the impact of products on the environment.

Clean production is an environmental management strategy that is both preventive and integrated that need to be applied continuously in production processes and product life cycle with the aim of reducing risks to humans and the environment (UNEP, 2003). Thus the net production focuses on the prevention of the formation of waste, which is one indicator of inefficiency. Means that prevention efforts must be made early in the process of production by reducing the formation of waste and waste utilization are formed through recycling. The success of these efforts will result in substantial savings for a significant reduction in production costs so that this approach can be a source of income (Anon, 2007).

The term net production was introduced by UNEP (United Nations Environment Programme) in May 1989 and submitted formally in September 1989 at the seminar on The Promotion of Cleaner Production in Canterbury, 
England. Indonesia agreed to adopt the definition given by the UNEP. Reducing the risk of cleaner production is meant in the sense of the security risks, health, environment and disappearance human and natural resources and the cost of repair or restoration (Indrasti \& Fauzi, 2009). Further stated that the net production is required as a strategy to harmonize environmental protection efforts with development activities or economic growth, prevent environmental pollution, maintain and strengthen economic growth in the long term, prevent or slow down the process of degradation of the environment and use of natural resources through the implementation of recycling the waste and to strengthen product competitiveness in the international market.

Clean Production can be used as a model of management of the environment by promoting high efficiency in an industry, so that the generation/waste results from the source can be prevented and reduced. The implementation of cleaner production will benefit the industry as it can reduce the cost of production, their savings, and environmental performance to be better. The implementation of cleaner production in an industrial area can be used as an approach to realizing the Industrial Area Environmental (Purwanto, 2005).

\subsection{Operating Revenues}

Revenue is something that is very important in every company. Without no income will be impossible to come by income. Income is income A rising from its activities commonly known or referred to sales, earnings services (fees), interest, dividends, royalties and rents (Cashmere \& Jakfar, 2007, p. 85). According to Cashmere and Jafar (2007, p. 85), there are two concepts of income, namely:

1) Concept revenue which focuses on inflows of assets as a result of operations company, and 2) income concepts focused on the creation of distribution of goods and services as well as consumer or other manufacturers.

Business costs According to Mulyadi (2002, p. 8), the cost is the sacrifice of economic resources.

Measured in units of money that has occurred or is likely to occur for specific purpose. According Soeharjo and Patong (1973, p. 14), the cost of farming or called also spending farming is the value of all inputs used up or incurred in the production. Farming costs may take the form of cash fees and charges were taken into account. Cash costs are the costs paid for with money, as it costs purchase of means of production and labor costs. Fees are calculated is used to quantify the employment income of farmers when the flowers capital and the value of family labor are taken into account.

Capital employed farmers calculated as though the loan capital.

The capital owned by the farmers themselves because the capital can be allocated to several cost alternative, so it should also take into account the farmer's own capital services, According Makeham and Malcolm (1991, pp. 98-101), the cost of the farm is divided be:

\section{Fixed cost}

Fixed costs are costs within the limits of any particular unchanged when level activities changed. Two kinds of fixed costs that have been known.

Common is the total fixed costs and operating costs.

Examples of fixed costs are: a. Investment, b. Depreciation, and c. Tax

\section{Variable Cost}

The variable cost is also known as direct costs. As the name implies, cost-These charges vary following the size and output level of an activity.

Examples of variable costs are: a. Employee Salaries, b. Raw material costs, c. Electricity cost

And telephone, and d. Transportation costs.

\subsection{Business Reception}

Soekartawi (1986, p. 76) argues that farm receipts is the money received from the sale of farm products which can manifest in three ways namely the sale of products that will be sold, the sale of by-products, and products consumed by households during farming activities. According to him, the production value of farm receipts is derived from the total product multiplied by the selling price.Gains and Cost Analysis Ratio (Net B/C ratio) Gains and Cost Analysis Ratio (Net B/C ratio) is a comparison between the level of profits to the total costs incurred. An attempt is feasible and beneficial if the value of the Net B/C is greater than zero (0), the greater the value of the Net B / C, the greater the benefit to be derived from such business (Rahardi \& Hartanto, 2003, p. 69). According Sofyan (2003, p. 177), Ratio Analysis Gains and Costs (Net B/C ratio) is a ratio that compares the 
benefits or advantages of a business by the costs incurred to realize the plan of the establishment and operation of the business.

\section{Payback Period (PP)}

Payback Period or the analysis of investment return time is a period required to close back investment spending.

Using cash flow (Cashmere \& Jakfar, 2008, p. 98). According to Sofyan (2003, p. 181), Payback Period is the period of return on capital, which means that a long period of time to recoup the investment. Very fast or slow depending on the nature cash flow influx. If a large influx of cash flow or current, then the process Payback will be faster with the assumption of fixed or capital employed no capital increase during the life of the project.

\section{Payback points (Break Event Point)}

Analysis of return of goods is an analytical tool used to determine the relationship between several variables in the company activities. As production area or the level of production that is carried out, the costs incurred and income received by the company from operations (Umar, 2005, p. 202).

According Rahardi and Hartanto (2003, p. 70), Break Even Point is Business break-even point. If the value of Break Even Point can be known, then the level Production and the price of how a business is not profitable and is not also suffered losses.

\section{Fish fillet}

\section{1) Definition Fish Fillet}

Fillet is part of the fish meat obtained by slicing a whole fish along the spine, starting from the back of the head to near the tail spine and ribs that limit the body to the abdominal cavity is not truncated at the time slicing. Fillet has several advantages as a material Processed raw, among others, free of thorns and bones, can be stored for longer, as well as can save time and labor for handling easier, so will facilitate and streamline production processes and improving the quality dairy products. Such as fillet Salmon (Anabas Testudineus), Red Snapper (Lutjanus argentimaculatus), grouper (Serranidae), Kurisi (Nemipterus nematophorus), Swanggi (Priacanthus tayenus), Seeds Jackfruit / kuniran (Upeneus sulphureus), bananas (Caesio chrysozomus), Paperek (Leiognathus sp), and gerot-gerot (Pomadasys sp) (Suparno, 2008, p. 2).

\section{2) Fish Fillet Type}

The fish are usually the raw material to be used as a fish fillet is marine and freshwater are medium-sized with a round or flat. Types of fish which is used as raw material for processing A variety of fish fillets kind, either sea fish or freshwater fish generally medium size, with fish body shape round or flat. Freshwater fish are usually be material to serve as fillet namely: Catfish, Tilapia, Gurame and Goldfish, while sea fish ie snapper, salmon, grouper, Pari, Tuna and others.

\section{Previous Research}

Kusumawarni (2003) on the income level of Farmers ornamental fish hatchery fresh water ornamental fish and fish consumption. Based on these studies, there was information that the revenue that the freshwater fish farmers for one year from Rp. 28.8 million with a value of R/C ratio of 6.24 percent. Meanwhile, for the three types of fish consumption, the income of Rp. 932,408.81 with a value of R/C ratio of 2.24 percent. Alireza (2002) with a study entitled "Feasibility Study Freshwater Ornamental Fish Agribusiness Small Scale" generate a positive NPV of Rp. 22,095,717, an IRR of 68.97\% and Net B/C ratio of 3.95, and its payback period of 3 years and 11 months. While large-scale efforts to produce NPV Rp. 51,950,085, an IRR of $84.28 \%$, Net B/C ratio of 4.54 and with a payback period of 3 years 1 month. This shows that agribusiness freshwater fish both small scale and large scale is still feasible. The results of the sensitivity analysis shows that agribusiness freshwater fish large scale are less sensitive to changes in output prices, input prices and interest rates. Each price increase output by $25 \%$, increase in input prices by $15 \%$, reduction in input prices by $15 \%$ and the interest rate increases to $20 \%$ does not cause the business is not feasible. While agribusiness freshwater fish is not worth it if there is a decrease in input prices is followed by a rise in interest rates. Inayah (2006) on the analysis of the rice farming income earned net income of farmers owner is Rp. 3.11 million and peasants $\mathrm{Rp} .1,750,000$. $\mathrm{R} / \mathrm{C}$ ratio of 1.5 for the farmer owners and sharecroppers of 1.26 which means that rice farming is efficient and viable and provide income that is greater than the costs incurred.

\section{Research Methods}

\subsection{Material}

The main raw material used in this study is a waste processing Siamese catfish (Pangasius hypopthalmus) 
cultured in Kampar, Riau. It is also used to process materials catfish processing solid waste into functional components of food and chemicals for quality analysis (hexane, filter paper, $\mathrm{K} 2 \mathrm{~S} 04, \mathrm{H} 2 \mathrm{~S} 04, \mathrm{HgO}, \mathrm{NaOH}$, H3B03, Hel, and Na2S203 and packaging materials.

\subsection{Implementation Research}

This study was conducted in several stages, as follows: Environmental risk analysis Analysis of the fish processing waste conducted by survey method, ie observing the types of waste, sewage and waste handling. The parameters measured were the process of waste treatment and disposal as well as other relevant data. A hierarchical method is used for a reference/qualitative matrix. In the matrix used methods/ways hierarchical levels, with a matrix form, chances are ranked according to how often the risk will occur and the magnitude ranked based on strong and great impacts. Identify the risks that may arise can use environmental indicators and impact as shown in Table 2 below.

Table 2. Risk identification

\begin{tabular}{cc}
\hline Indicator Environment & Influence Waste \\
\hline Land use (land) & No / No \\
The air quality & No / No \\
Noise & No / No \\
Water quality & No / No \\
Flora land & No / No \\
Flora water & No / No \\
land fauna & No / No \\
aquatic fauna & No / No \\
structure of the population & No / No \\
The level of public health & No / No \\
The level of income & No / No \\
environmental aesthetics & No / No \\
\hline
\end{tabular}

In this analysis will be used method of qualitative analysis (Idris, 2003). With this method of qualitative analysis will be made matrix combination of the probability of risks, the risks and value of the level of risk as Table 3 .

Table 3. Matrix level opportunities, the value of the magnitude and level of risk

\begin{tabular}{lccc}
\hline indicators & level Opportunities & value Magnitude & Level risk \\
\hline 1. Changes in land use & $\mathrm{A} / \mathrm{B} / \mathrm{C} / \mathrm{D} / \mathrm{E}$ & $1 / 2 / 3 / 4 / 5$ & $\mathrm{~T} / \mathrm{S} / \mathrm{R}$ \\
2. Air pollution & $\mathrm{A} / \mathrm{B} / \mathrm{C} / \mathrm{D} / \mathrm{E}$ & $1 / 2 / 3 / 4 / 5$ & $\mathrm{~T} / \mathrm{S} / \mathrm{R}$ \\
3. Pollution of groundwater & $\mathrm{A} / \mathrm{B} / \mathrm{C} / \mathrm{D} / \mathrm{E}$ & $1 / 2 / 3 / 4 / 5$ & $\mathrm{~T} / \mathrm{S} / \mathrm{R}$ \\
4. Pollution of surface water & $\mathrm{A} / \mathrm{B} / \mathrm{C} / \mathrm{D} / \mathrm{E}$ & $1 / 2 / 3 / 4 / 5$ & $\mathrm{~T} / \mathrm{S} / \mathrm{R}$ \\
5. Decrease the amount of ground flora (terrestrial) & $\mathrm{A} / \mathrm{B} / \mathrm{C} / \mathrm{D} / \mathrm{E}$ & $1 / 2 / 3 / 4 / 5$ & $\mathrm{~T} / \mathrm{S} / \mathrm{R}$ \\
6. Decrease the amount of water flora (aquatic) & $\mathrm{A} / \mathrm{B} / \mathrm{C} / \mathrm{D} / \mathrm{E}$ & $1 / 2 / 3 / 4 / 5$ & $\mathrm{~T} / \mathrm{S} / \mathrm{R}$ \\
7. Decrease the amount of land fauna & $\mathrm{A} / \mathrm{B} / \mathrm{C} / \mathrm{D} / \mathrm{E}$ & $1 / 2 / 3 / 4 / 5$ & $\mathrm{~T} / \mathrm{S} / \mathrm{R}$ \\
8. Decrease in the number of aquatic fauna & $\mathrm{A} / \mathrm{B} / \mathrm{C} / \mathrm{D} / \mathrm{E}$ & $1 / 2 / 3 / 4 / 5$ & $\mathrm{~T} / \mathrm{S} / \mathrm{R}$ \\
9. The decline in the level of public health & $\mathrm{A} / \mathrm{B} / \mathrm{C} / \mathrm{D} / \mathrm{E}$ & $1 / 2 / 3 / 4 / 5$ & $\mathrm{~T} / \mathrm{S} / \mathrm{R}$ \\
10. Reduced environmental aesthetics & $\mathrm{A} / \mathrm{B} / \mathrm{C} / \mathrm{D} / \mathrm{E}$ & $1 / 2 / 3 / 4 / 5$ & $\mathrm{~T} / \mathrm{S} / \mathrm{R}$ \\
\hline
\end{tabular}
Information :

$$
\begin{aligned}
& \text { Level opportunities are: } \\
& \text { A }=\text { Definitely going } \\
& B=\text { likely } \\
& \text { C }=\text { The possibility of being } \\
& D=\text { Possible small } \\
& \text { E }=\text { Rarely }
\end{aligned}
$$

The risk level is:

$\mathrm{T}=$ High

Medium $=$ Low
$2=$ minor Effect

3 = moderate influence

$4=$ great influence

$5=$ Disaster 
Stages Research

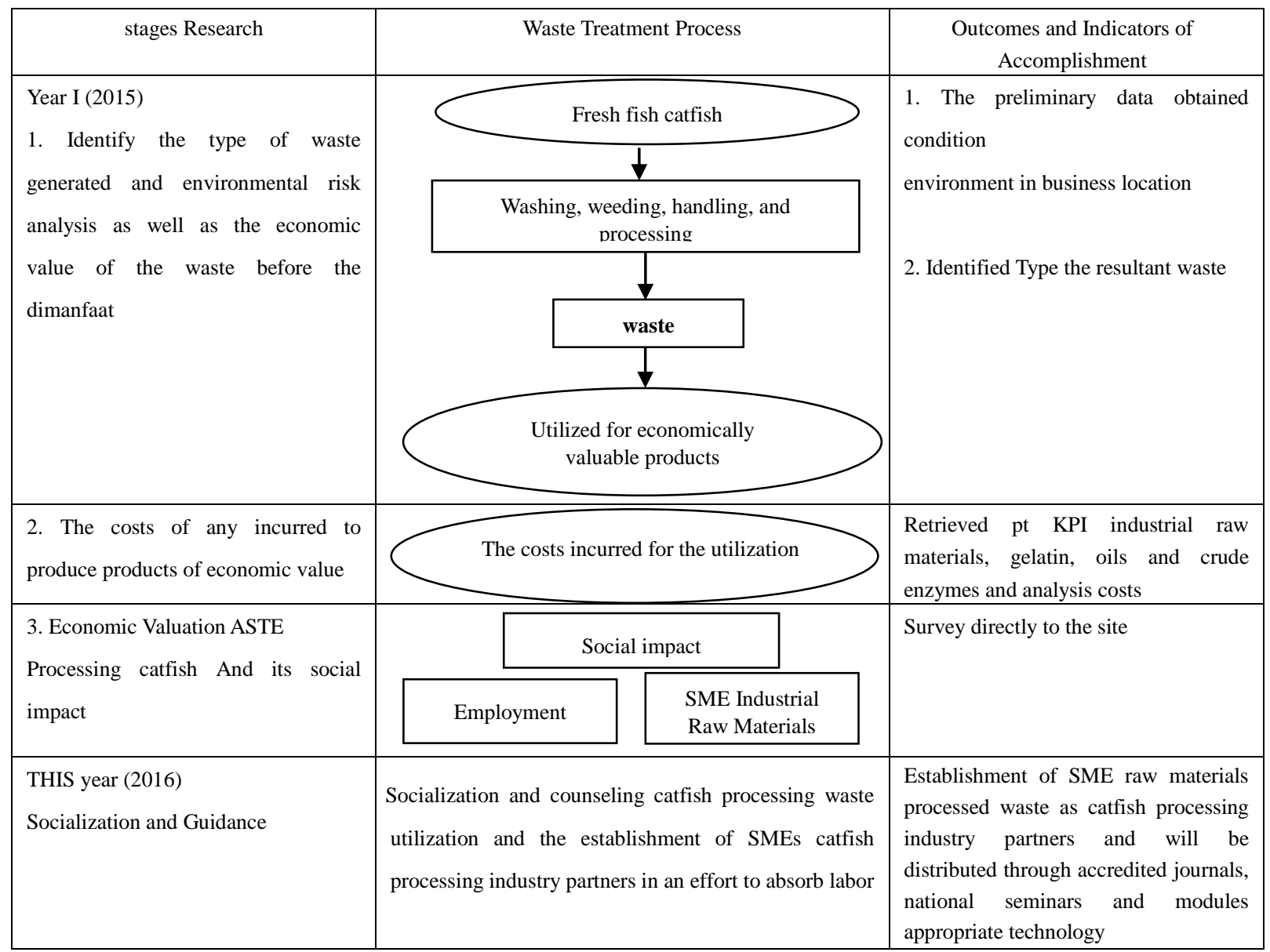

The process of Fish Processing Waste Utilization Patin

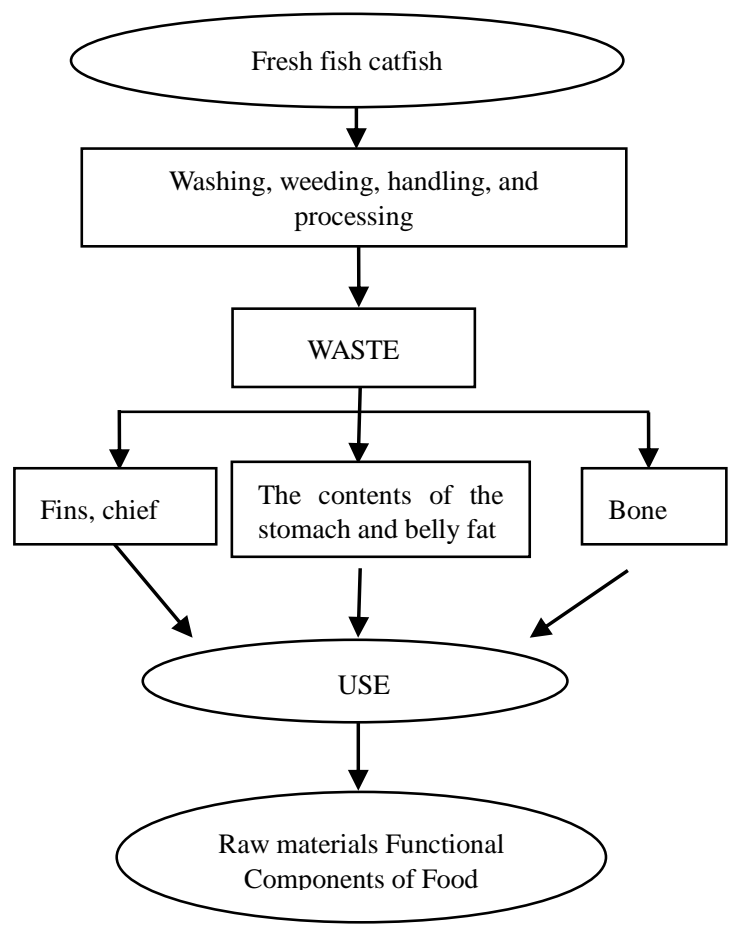




\section{Economic Valuation Waste Utilization}

Economic valuation is a way to give a quantitative value of the goods and services produced by natural resources and the environment irrespective of whether the market value (market value) is available or not. Although the environmental benefits are often not quantifiable and can not be judged by the price, the real value of the use of collective goods can be greater because of its uniqueness, so if used in excess can cause extinction. Valuation or assessment of the economic utilization of fish waste is the process of identifying, measuring, and assign economic value that can be utilized from fish processing waste. Economic assessment of fish waste utilization can be made based on the value of direct benefits, indirect benefits, the option value, and the value of the inheritance of the environment the fish processing industry. So in determining the value (economic valuation) the utilization of fish waste is done through the stages succinctly, namely: 1) Identify the impact of environmental damage caused by waste disposal fish processing, 2) to identify the spread of damage or pollution, whether polluting be local or may be widespread, 3) Identify the level or intensity of damage; aims to determine the extent of the damage, whether the category is large, medium and light, 4) Identifying resources and the environment are damaged; This identification will based on the direct benefits, indirect benefits, benefits selection, and inheritance benefits, and 5).Valuasi economic utilization of fish waste is done through economic valuation techniques that already exist.

\section{Data Analysis}

This research was conducted with experimental methods and data obtained do if the data, and then tabulated the processed data will be analyzed by descriptive statistics and simple.

\section{Results and Discussion}

\subsection{Identification of the Type of Fish Processing Solid Waste}

According to Law No. 31 of 2004 which states that fisheries are all activities related to the management and utilization of resources fish resources and the environment ranging from pre-production, processing to marketing, which is implemented in a system. The positive impact of fish processing enterprises one of which is the expansion of employment opportunities, income generation, and improving standards of living, small fishermen, small fish and parties entrepreneurs in the field of fisheries.

The development of fishery and aquaculture industries in the production center catfish in Kampar, positive impact on the local community for the development of domestic industry processing catfish like curing fish, fish fillets, and diversification of processed foods based catfish such as meatballs, nuggets, burgers and shredded catfish.

However, because most of the domestic industry is being implemented with limited knowledge about the environment, the negative impact pangasius fish processing industry began to cause disruption to the surrounding environment, especially when the waste is not treated and managed properly. This is due to the reluctance of businesses still burdened with external costs and the lack of awareness of waste management fishing industry. Catfish processing activities have meat yield of $50-60 \%$, that leaves $40-50 \%$ as wastes consisting of head, skin, viscera and bones. Based on these data, the processing of catfish solid waste about half of bobotc fish, the catfish processing waste utilization is very potential to be a source of food and feed.

The observations in the field, that the catfish processing activities identified solid waste in the form of entrails, head, fins, tail, belly fat, skin and bones. In general, processing businesses have not applied the principle of clean production, in which the solid waste generated is still accumulate at the site of treatment in an open, causing disruption to the environment in the form of a fairly pungent odor.

\subsection{Analysis of Potential Environmental Risks}

The study on the environmental impact of waste fish processing conducted by survey method, ie observing the types of waste, sewage and waste handling. The analysis is done by comparing the potential risks of existing conditions with environmental parameters so it can know the level of risk. In this analysis used a hierarchical method in the form of reference / qualitative matrix. In the matrix used methods / ways hierarchical levels, with a matrix form, chances are ranked based on how potential risks occurring and the magnitude ranked based on strong and great impacts. Identify the risks that may arise can use environmental indicators and impact as shown in Table 4 below. 
Table 4. Identification of potential risks

\begin{tabular}{lc}
\hline Environmental indicators & Influence Waste \\
\hline Land use (land) & There is no \\
The air quality & There is \\
Noise & There is no \\
Water quality & There is no \\
Flora land & There is \\
Flora water & There is no \\
land fauna & There is no \\
aquatic fauna & There is no \\
structure of the population & There is no \\
The level of public health & There is \\
The level of income & There is \\
environmental aesthetics & There is \\
\hline
\end{tabular}

In this analysis will be used method of qualitative analysis (Idris, 2003). With this method of qualitative analysis will be made matrix combination of the probability of risks such as Table 5 and the magnitude of risk in Table 6 that will produce a high risk value, medium or low as shown in Table 7.

Table 5. Matrix risk opportunities

\begin{tabular}{lcc}
\hline Environmental indicators & level Opportunities & commentary \\
\hline 1. Changes in land use & $\mathrm{D}$ \\
2. Air pollution & $\mathrm{A}$ \\
3. Pollution of groundwater & $\mathrm{D}$ \\
4. Pollution of surface water & $\mathrm{D}$ \\
5. Decrease the amount of ground flora (terrestrial) & $\mathrm{D}$ \\
6. Decrease the amount of water flora (aquatic) & $\mathrm{E}$ \\
7. Decrease the amount of land fauna & $\mathrm{D}$ \\
8. Decrease in the number of aquatic fauna & $\mathrm{E}$ \\
9. The decline in the level of public health & $\mathrm{B}$ \\
10. Reduced environmental aesthetics & $\mathrm{A}$ \\
\hline
\end{tabular}

Note. Level opportunities are: $\mathrm{A}=$ Definitely going; $\mathrm{B}=$ likely; $\mathrm{C}=$ The possibility of being; $\mathrm{D}=$ Possible small; $\mathrm{E}=$ Rarely.

Table 6. Magnitude risk matrix

\begin{tabular}{lcc}
\hline Environmental indicators & value Magnitude & commentary \\
\hline 1. Changes in land use & 2 & \\
2. Air pollution & 2 & 2 \\
3. Pollution of groundwater & 2 \\
4. Pollution of surface water & 1 \\
5. Decrease the amount of ground flora (terrestrial) & 2 \\
6. Decrease the amount of water flora (aquatic) & 1 \\
7. Decrease the amount of land fauna & 2 \\
8. Decrease in the number of aquatic fauna & 4 \\
9. The decline in the level of public health & 2 \\
10. Reduced environmental aesthetics & & \\
\hline
\end{tabular}

Note. Magnitude value is: 1 = Influence does not mean; 2 = minor Effect; $3=$ moderate influence; 4 = great influence; $5=$ Disaster. 
Table 7. Matrix level of risk

\begin{tabular}{lccc}
\hline indicators & level Opportunities & value Magnitude & Level of risk \\
\hline 1. Changes in land use & $\mathrm{B}$ & 2 & $\mathrm{~S}$ \\
2. Air pollution & $\mathrm{A}$ & 1 & $\mathrm{R}$ \\
3. Pollution of groundwater & $\mathrm{D}$ & 2 & $\mathrm{R}$ \\
4. Pollution of surface water & $\mathrm{B}$ & 3 & $\mathrm{~S}$ \\
5. Decrease the amount of ground flora (terrestrial)) & $\mathrm{B}$ & 2 & $\mathrm{~S}$ \\
6. Decrease the amount of water flora (aquatic)) & $\mathrm{B}$ & 1 & $\mathrm{R}$ \\
7. Decrease the amount of land fauna & $\mathrm{D}$ & 2 & $\mathrm{R}$ \\
8. Decrease in the number of aquatic fauna & $\mathrm{E}$ & 1 & $\mathrm{R}$ \\
9. The decline in the level of public health & $\mathrm{B}$ & 2 & $\mathrm{R}$ \\
10. Reduced environmental aesthetics & $\mathrm{A}$ & 4 & $\mathrm{~T}$ \\
\hline
\end{tabular}

Note. The risk level is: $\mathrm{T}=$ High; Medium $=$ Low.

Based on the analysis of Table 7 shows that the presence of solid waste processing results catfish showed the average level of potential environmental risk is quite low but the risk reduction in environmental aesthetics, because they interfere with the beauty and cleanliness of the environment. This is because the industrial solid waste food, especially the fish processing industry is an organic material such as carbohydrates, protein, fat, crude fiber and water. These materials are easily biodegradable and cause pollution of the environment, especially causing a foul odor (Anonymous, 2007).

According Natsir (2012), the main problem of solid waste handling fish processing result was the construction of a waste treatment installation and behavior of businesses is still low level of conscious environment. Noting the problem, hence the need for good environmental management efforts in the development of fish processing business is environmentally sound. Alternative solutions to the problem is to apply the principles of cleaner production. CP (Cleaner Production) is a strategy to avoid the onset of industrial pollution through reduced waste generation (waste generation) at every stage of the production process to minimize or eliminate waste before any kind of potential contamination formed. The success of these efforts will result in savings (savings) is remarkable for a significant reduction in production costs so this approach becomes a source of income.

\subsection{Utilization of Economic Analysis of Solid Waste Processing Fish}

The implementation of cleaner production offers opportunities for businesses of fish processing to prevent an expensive investment and not productive for the means of downstream pollution control (end-of-pipe) and waste management. Through the implementation of cleaner production to improve efficiency, profitability, industry competitiveness in the international community, particularly for the manufacture of products that are focused on exports. Thus the main target of cleaner production program is to emphasize how the measures are practiced will generate economic benefits for the company. The economic profit with the implementation of clean production technologies in fish processing business can be viewed from two aspects, namely:

Recovery of materials, especially solid organic material.

Increased benefits for the environment.

Recovery of organic material from solid waste processing fish may be leftover meat on the bone processing fish fillets, fat stomach, head and bones, entrails (viscera) and skin. Solid waste can be utilized to produce fish meal (fish protein concentrate), bone meal, fish oil, crude enzyme and fish skin crackers.

To produce individual components of waste into valuable products economy required an analysis of economic indicators required in a feasibility study (feasible) effort. These indicators are the Net Present Value (NPV), Benefit Cost Ratio (BCR), Profitability Index (PI), and Internal Rate of Return (IRR).

\section{a. Net Present Value (NPV)}

NPV is the difference between expenditures and revenues that have been discounted using the social opportunity cost of capital as the discount factor, or in other words the cash flows expected in the future, discounted at this time. To calculate the required data on the estimated NPV of investment costs, operating costs, and maintenance as well as the estimated benefit / benefit of the proposed project. So the NPV calculations rely on a discounted cash flow techniques.

The result of the calculation of NPV for utilization of solid waste processing catfish can be found in Appendix 1 . From the calculations, the NPV value is 1.60 , meaning $>0$, then the effort is feasible. 


\section{b. Profitability Ratio (PR)}

Profit ratio is a measure to determine how far the effectiveness of management in managing the company. Functional activities include management effectiveness of management such as finance, marketing, human resources, and operations. The purpose of this ratio is to measure the overall effectiveness of management that can be seen from the profits generated

The calculation result of PR for utilization of solid waste processing catfish can be found in Appendix 1. From the calculations, the PR value is 2.60 mean> 0 , then the effort is feasible.

\section{c. Benefit Cost Ratio (BCR)}

Benefit Cost Ratio is one method of investment feasibility. Basically, the calculation method of investment feasibility is more emphasis on benefits (benefits) and sacrifice (cost/cost) a investation, can be a business or project. In general, the types of investments that are often used on projects where the benefit is a kind of direct benefits, benefits will be felt directly in the community at large.

The result of the calculation of the BCR for utilization of solid waste processing catfish can be found in Appendix 1. From the calculations, the value of BCR is 1.15 mean> 0 , then the effort is feasible.

\section{d. Internal Rate of Return (IRR)}

IRR is an indicator of the efficiency of an investment. A project/investment can be made if the rate of return (rate of return) greater than the rate of return if invested elsewhere (interest on bank deposits, mutual funds and others). IRR is used in determining whether the investment carried out or not,

The results of the calculation of the IRR for utilization of solid waste processing catfish can be found in Appendix 1. From the calculations, the IRR is $65.91>18 \%$, then the effort is feasible.

\section{Conclusions and Recommendations}

\subsection{Conclusion}

From the research that has been done can be summarized as follows:

1). The results of field observation, that the catfish processing activities identified solid waste in the form of entrails, head, fins, tail, belly fat, skin and bones. In general, processing businesses have not applied the principle of clean production, in which the solid waste generated is still accumulate at the site of treatment in an open, causing disruption to the environment in the form of a fairly pungent odor.

2). The results of the analysis of the potential environmental risks it is known that the presence of solid waste processing results catfish showed the average level of potential environmental risk is quite low but the risk reduction in environmental aesthetics, because they interfere with the beauty and cleanliness of the environment.

3). The results showed that the clean production technologies capable of producing industrial raw materials in the form of fish meal (fish protein concentrate (KPI), fish oil, bone meal and fish skin chips in accordance with the Indonesian National Standard. In terms of environmental impact assessments and analysis of core businesses NPV is 1.60; (Benefit Cost Ratio = 1.15>1), amounting to 2,607 Profitabilty Ratio>1, and an IRR of 65.91> $18 \%$, then the establishment of solid waste utilization catfish processing feasible for small scale industries held.

\subsection{Suggestion}

Based on the analysis of economic valuation conducted on the utilization of solid waste catfish processing, utilization of solid waste that otherwise feasible. Thus through this business can increase profits and revenues catfish processing businesses.

\section{References}

Agustono. (1996). Economic Value of Mangrove Forests for People (A Case Study in Muara Cimanuk, Indramayu). Master of Science Thesis (Unpublished), IPB Graduate Program, Bogor.

Anonymous. (2007). Waste Management of Food Industry. Directorate General of Small Medium Industry Department, Jakarta.

Barton, D. N. (1994). Economic Factors and Valuation of Tropical Coastal Resources. SMR-report 14/94. Centre for Studies of Environment and Resources, University of Bergen, Norway.

Bunce, L. L., \& Gustavson, R. K. (1998). Coral reef valuation: A rapid Socioeconomic assessment of fishing, water-sports, and hotel operations in the marine park Montego bay, Jamaica and an analysis of reef management implications. World Bank Research Committee Project \#RPO 681-05. 
Cesar, H. S. J. (1996). Economic Analysis of Indonesian Coral Reefs. Working Paper Series, World Bank, Washington DC.

Fahrudin, A. (2009). Economic Analysis Coastal Stewardship in Subang, West Java. Master of Science Thesis (Unpublished), IPB Graduate Program, Bogor.

Husein, U. (2005). Research Methods. Jakarta: Four Salemba.

Lindeboom, H. J., \& Sandee, J. J. (1989). Production and Consumption of Tropical Seagrass Fields in Easterm Indonesia: Measured with Bell Jars and microelectrodes. Netherlands Journal of Sea Research, 23, 181-190. http://dx.doi.org/10.1016/0077-7579(89)90012-4

Ministry of Marine Affairs and Fisheries Republic of Indonesia (MMAF). (2001). Country Status Overview (CSO): Exploitation and Trade of Reef Fishery in Indonesia. MMAF, International Marine Alliance (IMA) and EIA Foundation, Jakarta.

Sadono, S. (2004). Introduction to Macroeconomic Theory. Jakarta: Rajawali Press.

Spurgeon, J. P. G. (1992). The economic valuation of coral reefs. Mar. Poll. Bull., 24(11), 529-536. Elsevier Science Ltd., Pergamon. http://dx.doi.org/10.1016/0025-326X(92)90704-A

Suharsono. (2001). Condition of Coral Reef Resource in Indonesia. Oceanological Research and Development Centre, Indonesian Science Agency. Paper presented in the International Workshop on the Trade in Stony Corals: Development of sustainable management guidelines. Jakarta, April 9-12, 2001. C

Suparmoko. (2013). The Free Economic Valuation and Analysis. Natural Resources and Environment, BPFE, Yogyakarta.

Sutrisno, H. M. M. (2007). Financial Management (1st ed.). Yogyakarta.

Wallace, C. C., Richards, Z., \& Suharsono. (2001). Regional Distribution Patterns of Acropora and Their Use in the Conservation of Coral Reefs in Indonesia. Indonesian Journal of Coastal and Marine Resources, 4(1), $40-58$.

Yulianto, A. A. (2006). Fundamentals of Financial Management. Jakarta: Four Salemba.

\section{Copyrights}

Copyright for this article is retained by the author(s), with first publication rights granted to the journal.

This is an open-access article distributed under the terms and conditions of the Creative Commons Attribution license (http://creativecommons.org/licenses/by/4.0/). 